\title{
電気光学効果を用いた強誘電体セラミクス の分極分布の測定
}

\author{
正 員 新 妻 弘 明 (東北大) \\ 非会員 大和田 淳 一 (東北大) \\ 正員 佐 藤 利三郎 (東北大)
}

\section{1. まえがき}

透明强誘電体セラミクス $(\mathrm{Pb}, \mathrm{La})(\mathrm{Zr}, \mathrm{Ti}) \mathrm{O}_{3}$ の出現 は, 数々の新しい強誘電体応用の分野を切開くと同時 に, 強誘電体七ラミクスの分極犾態の新しい測定法を 提供した ${ }^{(1)(2)}$ 。

我々は，一定の電極の形状，分極条件に初ける分極 分布状態を $(\mathrm{Pb} 0.94, \mathrm{La0.06})\left(\mathrm{Zr}_{\mathrm{r} 0.65}, \mathrm{Tij}_{0.35}\right) \mathrm{O}_{3}$ の電気光学 効果 (Transverce electro-optic memory effect ${ }^{(7)}$ ) を 用いて観測を行なった。

振動子，弾性表面波素子などの強誘電体セラミクス 応用デバイスの多くは，強誘電体の分極状態を場所の 関数にしたり特定のベクトルをむたせることにより， その機能や応用範囲は大きく拡大するもの之思われ る。また現在の形熊のままでも，できるだけ一様な分 極状態を得るということは大切であり，その技術およ び分極状態の評価法を確立することは重要である。

我々の研究は，乙のような観点加ら，一様あるいは 場所の関数あるいは特定のベクトルをるった分極状態 を得るための分極処理法の開発，および，我々が研究 を行なっている強誘電体記録 ${ }^{(3)}$ （5) の記録再生機構の 解明を目的としている。

强誘電体セラミクスの分極現象は，乙れまで材料そ のむのの性質を明ら加にするという立場加ら，主に一 方向で一様に分極したときの特性について研究がなさ

Measurements on Polarization Distribution of Ferroelectric Ceramics using the Electrooptic Effect. By Hiroaki Nittsuma, Member, Jun-ichi Öwada, Non-member \& Risaburō Satō, Member (Faculty of Engineering, Tohoku University).

新管弘明：正是，乘北大学工学部通信工学科

大和田㬌一：非会冒，東北大学工学部通信工学科

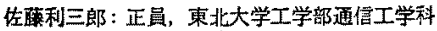

れてきており，不均一あるいは場所の関数として分極 したときの諸覞象に関する報告は数少ない。

本論文では，微小平行平板電極を装着した透明強誘 電体セラミクス $(\mathrm{Pb} 0.94, \mathrm{La0} 06)\left(\mathrm{Zr} 0.65, \mathrm{Ti}_{0.35}\right) \mathrm{O}_{3}$ 試料を 分極電界，分極時間，分極時の注入電荷などの分極条 件を変えて局所的に分極し，電極下およびその近傍の 分極分布状態を光学的に測定した結果を示し，分極分 布汇注目した分極の進行状況，分極反転過程など， $\left(\mathrm{Pb}\right.$. 94, Lac. 06) $\left(\mathrm{Zr}_{\mathrm{r} 0.65}\right.$ ， Tio. . .5 $) \mathrm{O}_{3}$ の局所的な分極過程の 最む基本的な性質を明らかにする。

\section{2. 実験方法ならびに試料}

一般に，複屈折物質真交ニコル間で単色光によっ て観測すると，その透過光の強さ $A^{\prime 2}$ は

$$
A^{\prime 2}=A^{2} \sin ^{2} 2 \theta \sin ^{2} \frac{\pi d \Delta n}{\lambda_{0}}
$$

ただし， $A^{2}$ : 入射光の強さ， $\lambda_{0}$ : 入射光の波長，

$\theta:$ 複屈折物質の光学軸之偏光子のなす角, $d:$ 複 屈折物質の厚み, $\Delta n:$ 複屈折率

と表わされる(6)。 $A^{\prime 2}$ は $\lambda_{0} 0$ の関数であるから白色光 のもとでは干渉色が観測され，乙の干涉色は厚み $d$ を一定とした場合，複屈折率 $\Delta n$ 上対応している。 熱消極された $(\mathrm{Pb}, \mathrm{La})\left(\mathrm{Zr}, \mathrm{T}_{\mathrm{i}}\right) \mathrm{O}_{3}$ を光路之莗直代分極 した場合，ての干涉色は分極値の等高線に，消光位は 分極の方向に対応して扔り，てのような測定により $(\mathrm{Pb}, \mathrm{La})(\mathrm{Zr}, \mathrm{Ti}) \mathrm{O}_{3}$ の分極の大きさ之方向の分布を知 ることができる(7)。

実験では直交ニコル系として POS 形偏光顕微鏡を 使用し，千涉色じまを測定した。更に干渉色図表 ${ }^{(6)}$ 用い $\Delta n$ の值に換算した。なお, 光源は白色光源に

昭 $53-3$ 
第 1 表 試料の諸定数

Table 1. Constants of sample.

\begin{tabular}{|c|c|}
\hline 組 成 & $\left(\mathrm{Pb}_{0,86,} \operatorname{La}_{0,06}\right)\left(\mathrm{Z}_{0,65,}, \mathrm{Ti}_{0,98}\right) \mathrm{O}_{3}$ \\
\hline 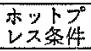 & 敢高保持湜度 $1,200^{\circ} \mathrm{C}$ ，保持時間 20 時間，区力 $210 \mathrm{~kg} / \mathrm{cm}$ \\
\hline 誘電特性 & $\begin{array}{l}\text { Curie 点 2000 } 20 \text {, 抗電界 } 8 \mathrm{kV} / \mathrm{cm} \text {, 蚫和 } \\
\mathrm{ms} \text { パルス分極) } 40 \mu \mathrm{C} / \mathrm{cm}^{2}\end{array}$ \\
\hline
\end{tabular}
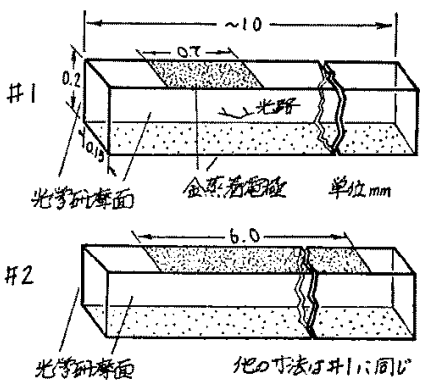

第 1 图 試料の形状

Fig. 1. Shape of samples.

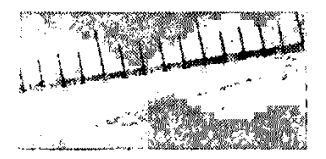

第 2 困 試料の概観

Fig. 2. View of samples.

色補正フィルタを加え，検光子を取り除いたときの試 料通過後の光が白色光になる上うに*, 試料の光吸収特 性（試料の色）を補正している。

試料は八戸工業大学 增田助教授作製のもので，諸定 数を第 1 表に示す。これを第 1 図に示すように加工， 光学研摩した。電極は平行平板状で片面は全面にわた り装着されている。電極は $\mathrm{Cr}-\mathrm{Au}$ をホトエッチング 法により装着した。また，試料作製㣪は残留忘力を取 り除くため空気中でアンニールした。第 2 困に試料の 概観を示す。

第 3 図に㬰験に用いた試料を幅 $10 \mathrm{~ms}$ の定電生パル スにより分極したときの分極特性を示す。そう図は それぞれの電界に和ける分極の時間変化を SawyerTower の回路により測定した結果である。これによ る之抗電界は $8 \mathrm{kV} / \mathrm{cm}$ 付近にあり，分極特性の立上 り付近の分極速度は飽和分極付近に比べかなり遅いこ とがわかる。第 4 図に，電極からみた試料の残留分極 $\bar{P}_{r}$ 亡複届率の平均値 $\overline{\Delta n}$ との関係を測定した結果 を示す。

\section{3. 実験結果}

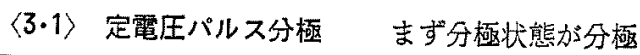

*:オリンパス EMM-6 形カラーバランスメータ集用

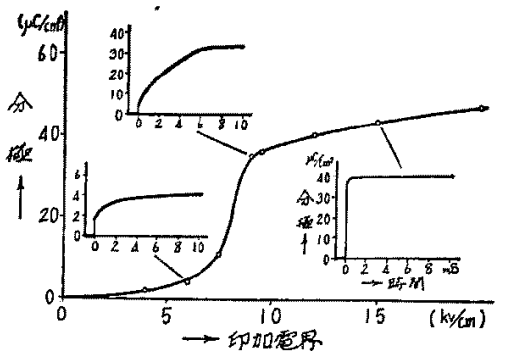

第 3 図試料の分極特性

Fig, 3. Poralizing characteristics of the sample.

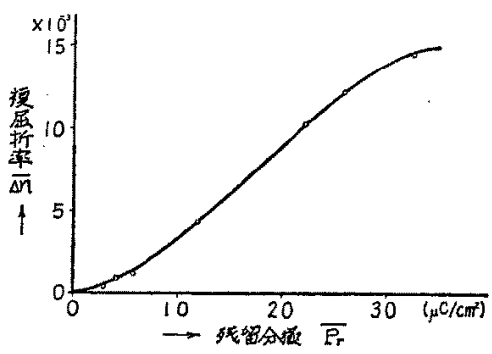

第 4 図 残留分極之複屈折率の関係

Fig. 4. Relation between remanent polarization and electrooptic birefringence.

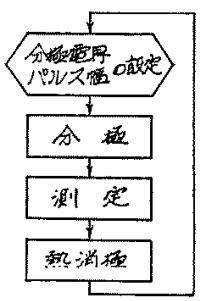

第 5 図実験の手順

Fig. 5. Experimental procedure.

電界，分極時間によりどのように変化するかを知るた めに，試料を定電壬パルスで分極し，そのときの残留 分極分布老測定した。定電圧パルスは水銀リレーを用 いたパルス発生器を用いて印加している。試料は第5 四に示すように测定でとに熱消極 $\left(330^{\circ} \mathrm{C} ， 25\right.$ 分，空 気中）を行なった。

第 6 図にパルス幅を一定とし電界を変化させたとき に，実際に影微鏡で 観測されるパターンを，第 7 図に それから複届折率江換算したパターンを示す。これに 上る之，（a）まず上面の電極付近だけが弱く分極し， それが対向電極们向かって成長して行き，(b)全体加 弱く（分極曲線の立上り付近）分極した時点で，上面 の電極端化分極の強い領域が現われ，(c)との領域が 試料中央汇向加って成長し，(d)中央まで達すると次 は外側に向かって成長を始め，(e)最釉的に電極下が 


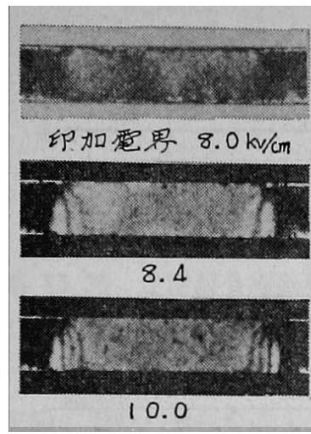

第 6 図 偏光顕微鏡による観測像

Fig. 6. Observed paterns under the polarizing microscope.

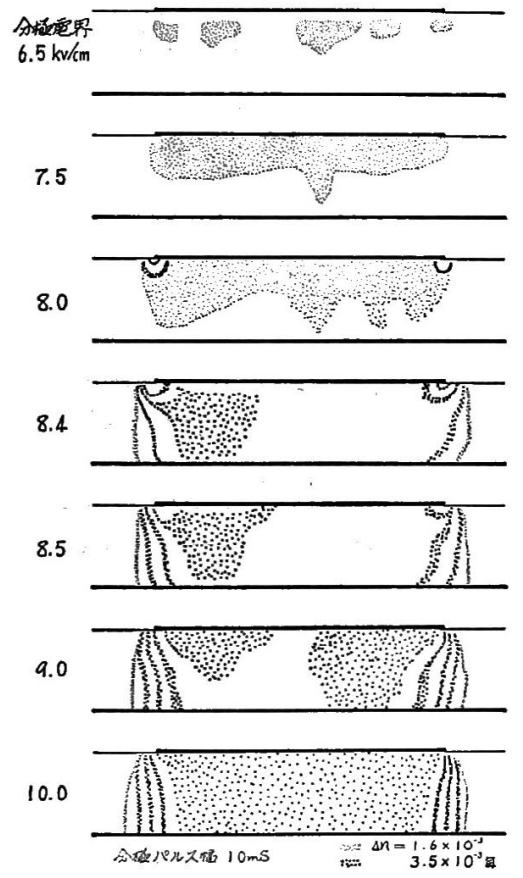

第 7 図 電界による分極分布の変化

Fig. 7. Dependence of the polarization pattern on the amplitude of the applied electric field pulse.

ほほー様なパターンに落着くことがわかる。電極端で の分極の広がりは飽和分極状態で $50 \mu \mathrm{m}$ （試料厚の 1/4) 程度であり, 印加電圧の符号によりこれらのパタ ーンが異なるよう.なととはない。また，てれらのパタ ーンは室温中では分極後の放置時間にはほとんど依存 しない。第 8 図に各パターンにおける分極の方向の分 布を測定した結果を示す。とれから知られるように， 分極の方向は電極下ではほぼ一様で電極に垂直であ り，電極外側では電極端から放射状に分布している。

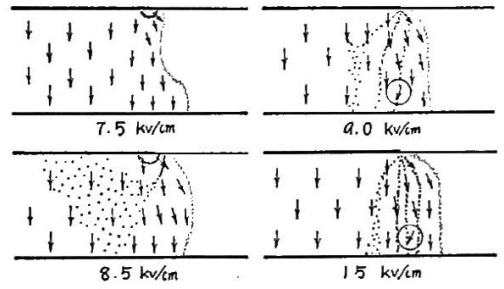

第 8 図 各パターンにおける分極の方向

Fig. 8. Distribution of the direction of the polarization.

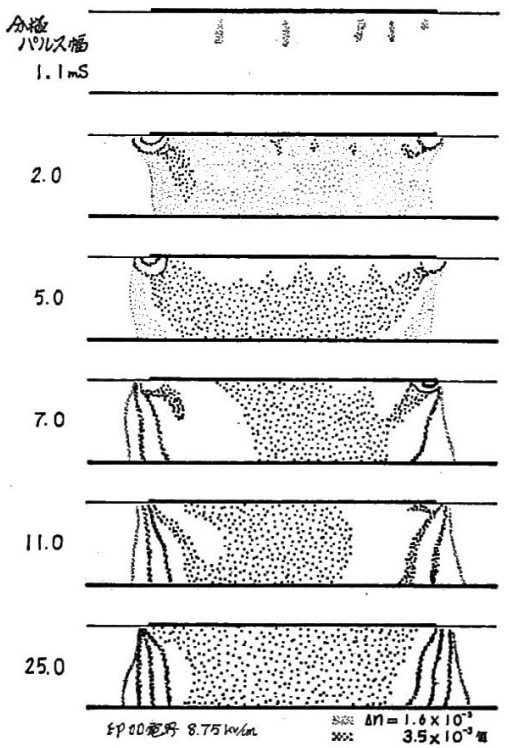

第 9 図 分極パルス幅による分極分布の変化

Fig. 9. Dependence of the polarization pattern on the duration of the applied electric field pulse.

また飽和分極の場合，○印の部分の分極の方向が対向 電極に垂直ではなく $7^{\circ} \sim 10^{\circ}$ 内側へ向いているが，乙 れは強誘電体特有の分極間相互作用によるすのと考え られ注目される。

第 9 図は電界を $8.75 \mathrm{kV} / \mathrm{cm}$ と抗電界よりやや大き な值に選び, パルス幅を変化させたときの様于である。 この結果は, 試料にステップ状の電界を加えたときの 分極の時々刻々の变化に対応している。この付近の電 界では分極は第 3 図に見られるように電界印加時間に 強く依存している。ての場合も第 7 図と同じような傾 向を示しており，時間的な分極の成長の仕方は電界を 増していったときと同様であるてとがわかる。

第 10 図は みに対して十分長い試料による実験の結果である。こ

昭 53-3 


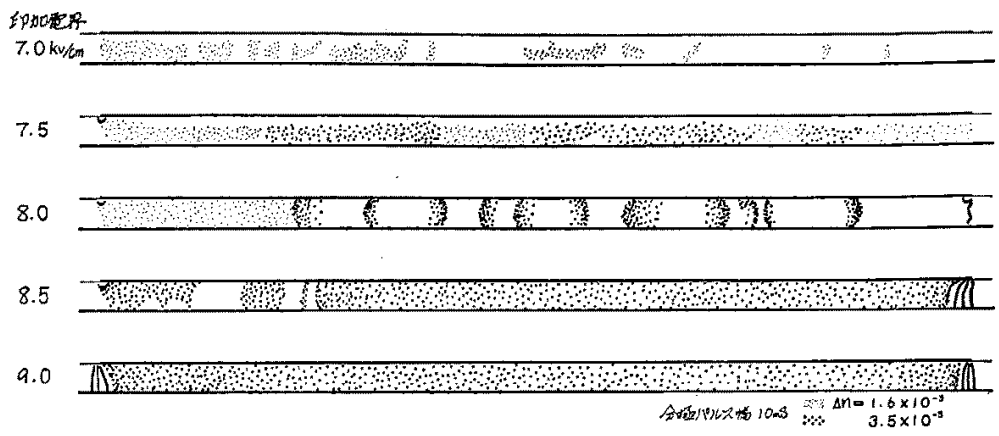

第 10 図 電界による分極分布の变化（試料，2）

Fig. 10. Dependence of the polarization pattern on the amplitude of the applied electric field pulse (Sample \#2).

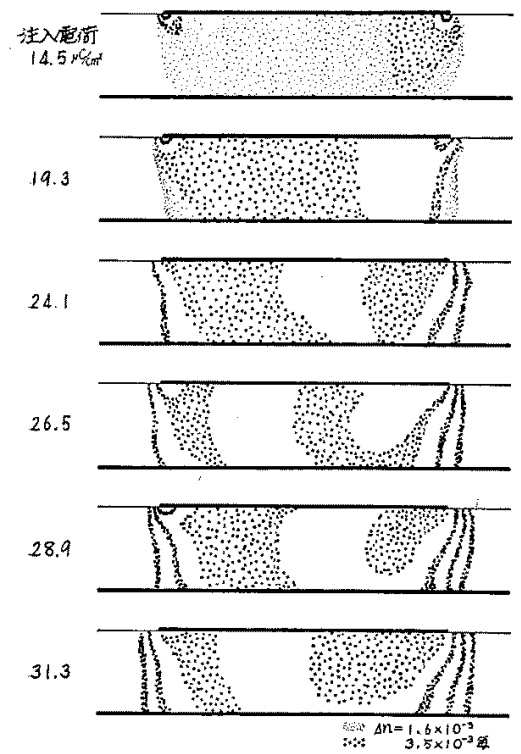

第 11 図 注入電荷量による分極分布の変化

Fig. 11. Dependence of the polarization pattern on the poured charge.

の場合は分極の変化の様子はてれまで示したものと異 なっている。すなわち，第 7 図や第 9 図のように電極 端から分極が進行するのではなく，電極下の不特定な 部分加ら始まっているてと，分極のパターン恬電極端 付近を除けばほぼ上下対称であること，分極の成長過 程に招いては，分極は球面状に広がっていくととなご の違いが認められる。

$\langle 3.2\rangle$ 定電荷分極 第 11 図, 第 12 図は定電荷 分極，すなわち電源加ら試料注入する電荷量を外的 に制御して分極したときの結果である。夷験では分極 回路に直列に抵抗をそう入し，注入電荷量が設定され た值になったとき，試料を短絡するような回路を用い

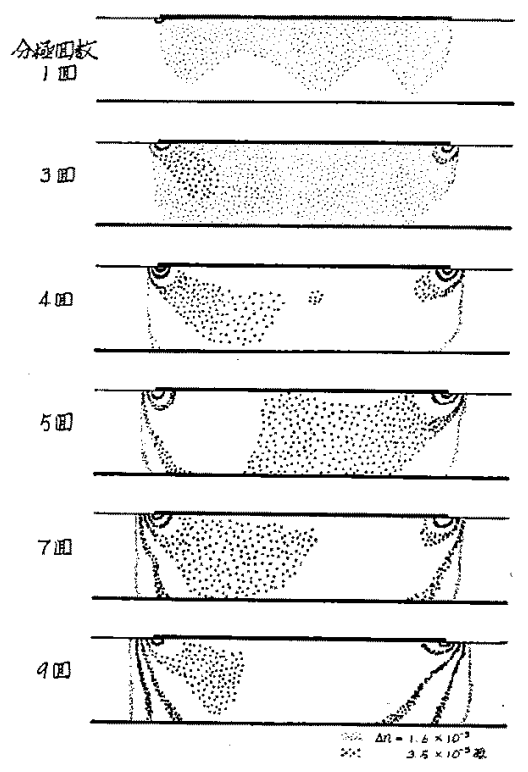

第 12 図 分極回数による分極分布の变化 Fig. 12. Dependence of the polarization pattern on the number of times of polarization

ている。本実験では分極が数十 $\mathrm{ms}$ で終了するように 抵抗の値を決定している。このような分極法は電界を 固定する定電生分極法に比へ，分極曲線の立上り付近 の任意の残留分極を容易に得ることができる(4)。

第 11 困は定電荷分極法により注入電荷量を変えて 分極した結果である。この場合むパターンは本質的に 定電王分極の場合と変わりはないが，分極進行の経過 がよく現われている。第 12 図は第 13 図に示すよう に定電荷分極を繰返し行なったときの結果である。と の結果に見ら机るように各パターンは連絸的に進行し て找り，試料第 13 図 $O A B C D$ と分極しても $O A C D$ と分極してす分極は同粎な成長をするとと 


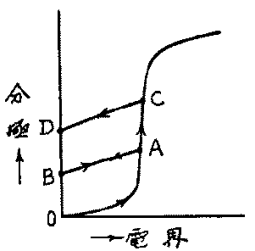

第 13 园定電荷分極過程

Fig. 13. Process of the constant charge polarization.

わ゙わかる。本実験の場合，分極処理と分極処理の間の 放置時間は室温で数分程度であったが，長時間放置し た場合どのようになるかは，空間電荷の影響む考えら れ(8)興味深い。

〈3.3〉 分極反転 次に, いった九飽和分極した 試料を迹方向に分極し，そのときの分極状態を測定し た。分極反転特性はメモリーなどの応用には重要な特 性である。

第 14 国に测定結果を示す。分極反転は前節と同様 に定電荷分極により行なっている。同图は飽和分極し た試料を逆方向に定電荷分極したときのパターンの变 化である。なお，1回の定電荷分極における注入電荷 量は $19.3 \mu \mathrm{C} / \mathrm{cm}^{2}$ である。乙れによると，5回の分 極により分極反転は完了している。また分極反転が進 行するにつれて分極パターンは対向電極の方から変化 が始まり， $\Delta n$ が極小になるような中間状態 ( 2 回目) を経た後，再び飽和分極状態へと移行する。ここで，

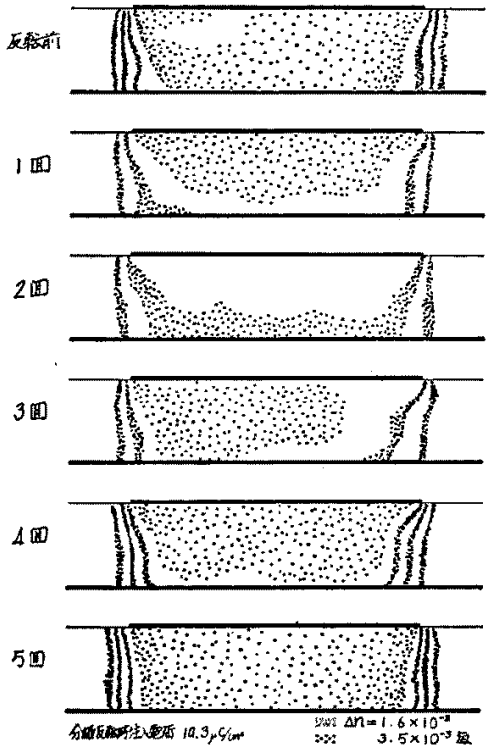

第 14 目 分極反転時の分極分布の変化

Fig. 14. Change of the polarization pattern in the switching process.

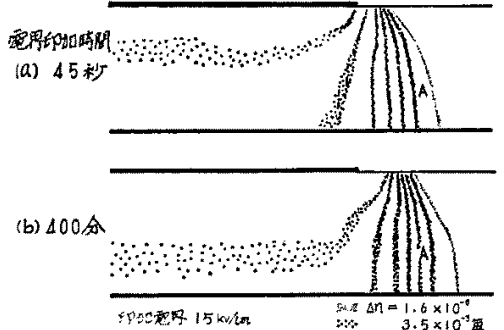

第 15 図 長時間分極におりる分極分布の変化

Fig. 15. Change of the polarization pattern with the duration of the applied field.

中間状態での分極状態は第 7 図などの不飽和分極状態 に比べ，電極下での均一性が良いととが応用上注目さ れる。

飽和から飽和への分極反転を繰返す実験む行なった が，数回の繰返しによりパターンは明確な中間状態を 経ずに直接飽和から飽和のパターンに移行する傾向を 示すようになることが確認された。

〈3.4〉電極端における分極の広がり 電極端に おりる分極の広がりは，メモリ一，画像蓄積素子なよ゙ の応用では情報密度に直接関係しており重要な意味を あつ。 $\mathrm{BaTiO}_{3}$ 単結晶の場合， $a$ ドメインを局所的に

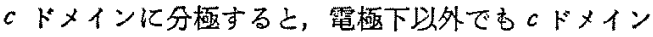
に移行する現象が報告されており (9)，強誘電体七ラミ クスの昜合どのようになるかは舆味深い。

前節までの実験結果により, $10 \mathrm{kV} / \mathrm{cm}, 10 \mathrm{~ms}$ 程度 のパルス分極では分極の広がりは $50 \mu \mathrm{m}$ (試料厚の 1/4) 程度であることを示したが，本節では電界を長時間印 加したときの電極端での分極分布の变化を測定した結 果を示す。分極電源には安定化定電王電源を用い, 15 $\mathrm{kV} / \mathrm{cm}$ の電界を目加しながら分極分布の变化を測定 した。

第 15 図〜第 17 図に測定結果を示す。第 15 㘡(a)

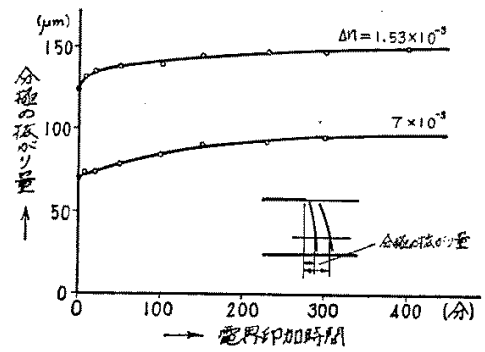

第 16 図 電極端におりる分極の広がりの 電界印加時間依存性

Fig. 16. Dependence of spread of polarization near the edge of the electrode on the duration of the applied field. 


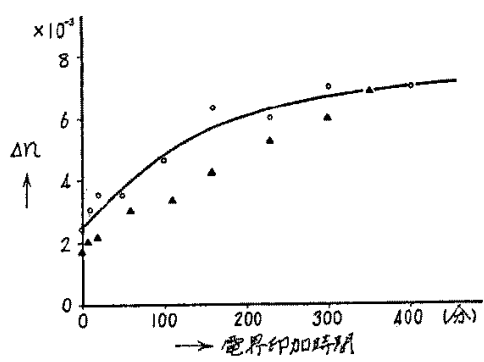

第 17 圆 電極端におりる分極值の 電界町加時間依存性

Fig. 17. Dependence of the polarization near the edge of the electrode on the duration of the applied field.

は電界印加 45 秒後の，（b）図は400 分後の分極分布 である。(b)図では（a）罒に比べ電極下の分極がわ ずかに增加し，電極端におりる分極の広がりが增大し ている。電極下の分烝の增加性数％程度であるが， とのような測定では干涉しまの位置の知動として比較 的はっきりと観測される。第 16 図は広がり量を電界 印加時間についてプロットしたすのである。てれによ ると，広がり䁷は時間とともに增加しているが，400 分程度でほほ螕和する傾向を示しており，分極が限り なく広がっているような現象は見られない。第 17 図 は第 15 図（a） $A$ 点における $\Delta n$ の時間的な增加 を示したすのである。図中 $\Delta$ 印は平行平板電極で $E_{c} / 2$ 程度の弱い電界を印加したときの，中央部の分極の時 間変化を示すすのである。とれによると雨者は同䊂な 傾向を示しており，長時間分極に拈りる電極端の分極 の広加りは，单なる試料自体の分極の㭙間依存性にほ かならないことを示している。

\section{4. 検 討}

以上の実験の結果，次の事が明らかになった。

（1）\#1の試料を $10 \mathrm{~ms}$ 程度の時間で分極した 場合，分極分布の変化は模式的に第 18 図の上うにな る(第 7 図，第 9 図，第 11 図，第 12 図)。

（2）時間的な分極の成長の仕方は電界を增したと きの成長の仕方と同様である(第 9 図)。

（3）不飽和分極状態では雪極下の分極は不均一て ある(第 7 図，第 9 図，第 11 図，第 12 园)。

（4）分極在いったん中断し，残留分極状態にした のち再び分極しても，中断しない場合と同样に分極が 進行する(第 12 因)。

（5）残留分極状態で室温で放置してむパターンは 変化しない。

（6）分極のパターンは卵加電圧の符号にはよらな (a)

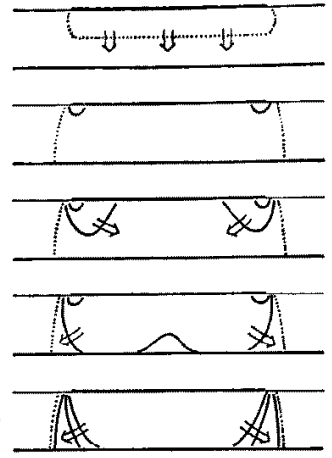

第 18 図極成長の模式図

Fig. 18. Illustration of the growth of the polarization.

(a)

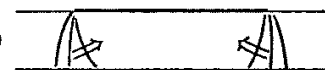

(b)

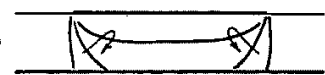

(c)

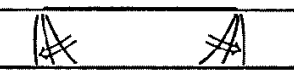

第 19 図 分極反転の模式図

Fig. 19. Illustration of the switching.

W。

（7）飽和分極の場合，分極のベクトルは対向電極 に垂直あるいは外側を向くとは限らず，内側を向く場 所がある(第 8 困)。

（8）電極端での分極の広がりは飽和分極時で試料 厚の $1 / 4$ 程度である(第7図)。

（9）飽和分極状態で長時間電界を印加してす分極 が限りなく広がることはない。

（10）電極の長さが武料厚に比べ十分長いような電 極形状では，分極電極下のある点（複数個のことむ ある)から成長を始め，それが球面状江がっていく。 また，その分極分布のパターンは電極端付近を除けば 上下対称となる(第 10 図)。

（11）いったん飽和分極した試料を逆分極すると第 19 図のように対可電極の方から変化が現われ，再びも とのパターンになる(第 14 図)。

（12）逆分極により作られた不館和分極状態では， 電極下の分極ははほ均一である(第 14 困)。

(13) 分極反転を繰返す之，分極のパターンの変化 は次第に不鮮明になる。

(1), (2), (4) 項の結果加ら (Pbo.94, La0.06)( $\mathrm{Zr}_{0.65,}$ Tio. 35) $\mathrm{O}_{3}$ の局所分極過程ては，笔極端のような電界 の集中した部分がいったん強く分極すると，その後は 
その部分から分極が広がっていくという一般的な傾向 を知ることができる。分極分布を決定する要因とし $\tau$,

（a）電極形状で決まる電界分布

(b) 試料の特性

（c）試料の特性の場所による違い

(d) 試料内の残留応力，ひずみ

(e) 分極間相互作用

（f） 分極速度の非線形性

（g）空間電荷

(h) その他

が考えられる。（a）は線形な系での電界分布に対応し たもの，(b)は組成，粒徍の違い，あるいはそれに上 る抗電界，飽和分極，結晶構造などの逢い，(c)はそ れらの場所に上る違いおよび欠陮，(d)はアニーリン グによってあ取り除けなかった残留応力，ひずみ（e) はいわゆるInteraction field(11)で電気的なむのと機械 的なすのが考元られる。(f)は分極速度が電界庶力 により変化することを指している。（g）は空間電荷の

\section{影瑤である。}

本実験で行なったような分極過程では，(a)（c)， (d)の要因により試料の市る部分が分極し，それが (e).(f)などの要因の影響を強く受けながら成長する すのと考元られる。(1)，(2)，(4)項の場合は(a) の要因が大きく効き，(10)項の場合は(c)，(d)が最

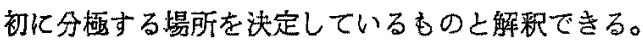

（a）の効果を調べるため亿，試料の誘電特性が線形 であり，誘電率が 1 より十分大きいとして等角写像法 により電界分布を計算した。第 20 図に結果を示す。 因は等電界強度線を表わしており，值は $E_{0}=V / d$

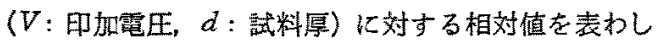
ている。これによると電極端では電極中央部の 2 倍の 電界がかかっており，乙の部分がまず強く分極するこ とは予想できる。しかし，実跧ではその㣪の分極成長 過程に抬いて，語算結果加予想される分極分布之は 異なったパターンを示しており，特に（7）項のベク トルが内側を向く現象などは全く説明がつかない。乙 れは分極成長過程では，(e）の分極間相互作用など の非線形な要团が主に効いているため上考えられる。

分極の成長過程では単結晶のようなくさび状の成 長 ${ }^{(10)}$ は起きず，球面状汇広がっているととを(1)， (2)，(10)項などの結果から知ることができる。この ことは，(5)項の残留分極のパターンが安定であるこ と, (6)項の甲加電圷の符号によらないととなどの性 㑭ととすに，強誘䉓体セラミクスは単結晶に比べ分極 を場所の関数にするような応用に適していることを示

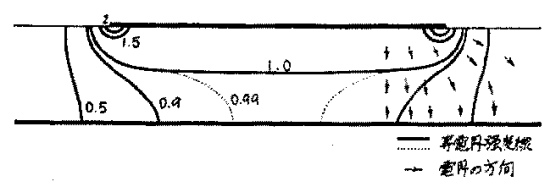

第 20 図 平行平板電極に上る電界分布 Fig. 20. Electric field distribution in the parallel plate electrodes.

している。

（a）の分極が電極下に限定されていること応用に 適した性貿であるが，乙れは試料の抗電界，飽和残置 分極の值左右されるむのと考无られる。乙机関し ては今後翼なった組成の試料で同様の実験を行ない， 材料定数之の関係を明ら玑する必要がある。

逆分極過程行捄いて，第 19 図に示したように対向 電極の方加ら変化が現わ机るのは不思議な現象であ る。なぜなら第 20 困の計算結果が示すように，線形 の系では笔極付近の電界加対向電極付近比比強いの であるから，単純に考えれば逆分極の際も分極の変化

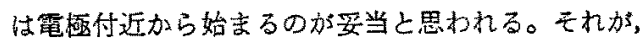
最後汇分極したところが逆分極過程では最初に変化し ているのは何か未知の要因が影響しているものと思わ れる。また，(13)項の分極反転を繰返すととによりパ ターンの変化が不鮮明になる現象が $180^{\circ}$ の反転によ るむのとすれば，Kruger ${ }^{(1)}$ や Keve ${ }^{(2)}$ 氏らの $「 71^{\circ}$ ， $109^{\circ}$ 反転が連続するととによって，実効的に $180^{\circ}$ 反 䎐が起こる」という結果と，どの上うに結びつくかが 問題である。

（3），(12）項の結果は，不飽和でかつ均一な分極を 得る目的には重要な結果である。このほ加，試料心温 度，電界の時間関数なども分極の均一性に影響する要 因であると考えられる。

\section{5.むすび}

微小平行平板電極在䒾着した $(\mathrm{Pb} 0.94, \mathrm{La0} .06)\left(\mathrm{Zr}_{0.65}\right.$, $\mathrm{Ti}$. $\left.{ }_{35}\right) \mathrm{O}_{3}$ 試料を，定電王パルス分極，定電荷分橾， 分極反䎐などの分極法により局所的に分極し，そのと きの電極下およびその近傍の分極分布の变化を光学的 に测定した。そる結果，電極の形状により電界の集中 した場所あるいは試料の特性として最す分極しやすい 部分がまず分極し，そてから分極が应かっていくこと， 残留分極分布は分極の飽和，不飽和に加加らず安定 であるとと，飽和分極状態で長時間電界を印加して屯 分極が電極下以外の場所へ広がっていくようなととは ないととなど，(Pb0.94，La0.06)(Zro.65, Ti0.35) $\mathrm{O}_{3}$ を局所 的に分極したときの現象の一部を明らかたするととが 
できた。

このように光学的な分極の測定は定性的ではある が，分極状態がパターンとなって現われるため情報量 が極めて豐富であり，これまでの測定法では測定しに くかった細かい分極の変化，メカニズムなどが比較的 容易に観測できる。

これらの分極のメカニズムを決定する要因について 極內て定性的に検詰を行なったか，各々の要因を正確 にはあくするためには，それなりの実験や理諭計算が 必要であるう。

ここでは応用上興昧ある分極現象を中心に述ぺた が，これらの結果はメモリー，ディスプレイなどの応 用や，ある特定の分有をもった分極を得るための技術 開発の基礎資料として役立つものと思われる。

本実硂では，最屯基本的な電界分布をるつものとし て平行平板電極它用いているが, 特殊な電極形状や移 動電界下での分極現象は今後の課題として與昧深い。 また，本実験では試料を(Pbo, 94,La0,06)(Zro.5,Ti0, 35) O3に限定して実験を行なったが，これらの結果が強 誘電体セラミクス全般にどこまで畺応できるかを明ら かにするためには，更に材料定数を変艺た芙駼を行な う必要がある。

終りに，本実驗氏用いた $(\mathrm{Pb}, \mathrm{La})(\mathrm{Zr}, \mathrm{Ti}) \mathrm{O}_{3}$ 試料安
提供して下さった八戸工業大学 増田陽一郎先生, 微小 試料の光学研摩をしていたたいた東北大学教盖部地学 科 巨野 功さんに感謝の意老表します。

(昭和 52 年 6 月 23 日受付, 同 52 年 10 月 17 日再受付)

\section{文献}

(1) E.T. Keve \& K. L. Bye: "Phase identification and do main structure in PLZT ceramics" J. Appl. Phys. 46, 810 (1975)

(2) G. Krüger: "Domain wall motion concept to describe ferroelectric rhompohedral PLZT ceramics." Ferroelect rics 11, 417 (1976)

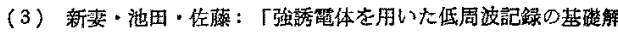
析」電学論 A, 94, 69 (昭 49-2)

（4）新婁・佐藤：「強誘笔体記録化拈ける定電流記録方式」同上 A, 95, 87 (昭 50-2)

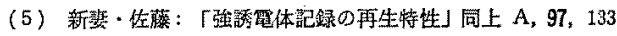
(昭 52-3)

（6）坪井：㾫光影微鏡（昭 34）岩波留沾

(7) C. E. Land, et al.: "Electro optic ceramics". Applied Solid State Science, (1974) Academic Press

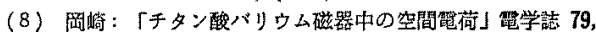
850 (昭 34-7)

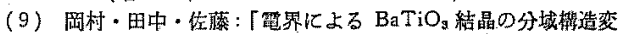
化の観察」昭 45 電気関䋆学会東北支部䝵大 $2 \mathrm{C}-11$

(10) E. A. Little: "Dynamic Behavior of Domain Walls in Barium Titanate" Phys. Rev. 98, 978 (1955)

(11) C. D. Mee: "The Physics of Magnetic Recording" 31 (1964) North.Holland Fublishing 